\title{
Effects of Nystatin, Fluconazole and Propolis on Poly(Methyl Methacrylate) Resin Surface
}

\author{
Wander José da SILVA ${ }^{1}$ \\ Rodrigo Nunes RACHED ${ }^{2}$ \\ Pedro Luis ROSALEN ${ }^{3}$ \\ Altair Antoninha DEL BEL CURY ${ }^{1}$ \\ ${ }^{1}$ Department of Prosthodontic and Periodontology, Dental School of Piracicaba, \\ State University of Campinas, Piracicaba, SP, Brazil \\ ${ }^{2}$ Department of Dentistry, Pontifical Catholic University of Paraná, Curitiba, PR, Brazil \\ ${ }^{3}$ Department of Physiology, Dental School of Piracicaba, State University of Campinas, Piracicaba, SP, Brazil
}

\begin{abstract}
The prevalence of candidosis in denture wearers is as well established as its treatment with antifungal agents (AAs). However, little research has been done regarding the effects of AAs on denture base surfaces. Therefore, the aim of this study was to evaluate the effects of fluconazole (FLU), nystatin (NYS) and propolis orabase gel (PRO) on poly (methyl-methacrylate) (PMMA) surfaces. Deionized water and orabase gel without any active component were used as control groups. Conventional heat-polymerized (Clássico) and microwave-polymerized (Onda Cryl) acrylic resins were used. After polymerization, the specimens were polished and had their surfaces evaluated for roughness, free energy and Knoop hardness. Subsequently, specimens were immersed in AAs and controls for 14 days at $35 \pm 2{ }^{\circ} \mathrm{C}$ and all variables were measured again. Data were analyzed statistically by 2-way ANOVA followed by Tukey's test $(\alpha=0.05)$. Roughness results showed similar behavior for both PMMA resins, with PRO reaching the highest values and differing significantly from the other AAs $(p<0.05)$. No statistically significant differences $(p>0.05)$ were found between the two PMMA resins or between NYS and FLU as regards surface free energy. In conclusion, PRO was able to induce changes in PMMA surface properties, such as roughness, which could be related to microbial adhesion.
\end{abstract}

Key Words: fluconazole, nystatin, propolis, antifungal agents, surface properties.

\section{INTRODUCTION}

Chronic erythematous candidosis (CEC) is the most prevalent form of oral candidosis and it affects more than $65 \%$ of denture wearers. The association of Candida species to CEC is due to their ability to colonize hard oral substrata, including denture materials. Thus, denture wearing is recognized as a predisposing factor for oral colonization by Candida (1-3).

Although poly(methyl methacrylate) (PMMA) resin is a potential substratum for Candida adhesion (2,3), characteristics like esthetics, easy manipulation, reasonable cost, and being inert to oral and other tissues make PMMA an elective material for denture bases. Initially, acrylic resins were heat polymerized by hot water bath, and later the microwave energy was introduced, as it saves polymerization time and is convenient in dental laboratories, thus expanding the use of this material (4).

Microbial adherence to PMMA surfaces may be initially attributed to non-specific interactions (electrostatic, van der Walls forces and acid-base interactions) and subsequently to specific interactions (receptor ligand binding) (2). Furthermore, PMMA properties, such as surface roughness (SR) and surface free energy (SFE) may contribute to the correlated rate of microbial colonization and biofilm maturation on oral surfaces $(2,5,6)$. SFE is an important property because it indicates how easy saliva spreads over a surface $(5,7,8)$ regulating the components responsible to form acquired pellicle. In addition, surface characteristics, such as microtips, microporosities and roughness, may harbor 
microorganisms that are difficult to remove by mechanical or chemical cleansing (3), thus increasing the adherence of microorganisms in vitro.

CEC is commonly treated with topical antifungal agents (AAs) such as nystatin (NYS) and systemic fluconazole (FLU). Although the initial inflammatory condition is reduced, clinical aspects are recurrent after treatment suppression $(9,10)$ and therapy failure is not uncommon (11). Thus, the continuous interaction between AAs' chemical components in CEC treatment could compromise the PMMA resin properties and favor microorganism adhesion. Moreover, the denture surface can act as a microorganism reservoir facilitating denture user re-infection (1).

Natural products are been increasingly used in oral disease prevention and propolis is considered the most promising one. Propolis is a non-toxic resinous hive product collected by Appis mellifera bees from various plant sources, and has been recognized as having several properties that confer health benefits to humans, including prevention of oral diseases. It has shown antimicrobial activity against oral pathogens, such as Candida albicans (12).

Although the effects of AAs on CEC treatment and against Candida species have been extensively investigated, little is known about their effect on PMMA, which is commonly used in denture bases. Therefore, the purpose of this study was to evaluate the effects of FLU, NYS and propolis orabase gel (PRO) on the surface properties of PMMA resins.

\section{MATERIAL AND METHODS}

\section{Antifungal Agents}

The following AAs used were PRO, FLU reference powder (UK - 049858, kindly donated by Pfizer, Sandwich, UK) and NYS reference powder (Sigma-Aldrich Corp., St. Louis, MO, USA). FLU and NYS were prepared using reference powders and deionized water at $2.56 \mu \mathrm{g} / \mathrm{mL}$ (maximum concentration found in human saliva after biotransformation) (10) and $3.12 \mu \mathrm{g} / \mathrm{mL}$ (minimal inhibitory concentration (MIC) for Candida species) (13), respectively. Deionized water was used as a control for both AAs. PRO was prepared from an ethanolic extract of propolis (EEP) obtained from crude samples of Apis mellifera bees in the south of Brazil, classified as type SNB-RS $(12,14)$.
The crude was extracted using aqueous ethanol $80 \%$ (v/ v) and a solution of $10 \%$ EEP was prepared, in accordance with Koo and Park (14). The AA containing propolis was prepared by adding carbopol orabase gel to the EEP solution. The gel concentration was $400 \mu \mathrm{g} /$ $\mathrm{mL}$, which is the MIC against Candida albicans (12). The control group for PRO orabase gel was orabase gel prepared without EEP, but ethanol was added in the same concentration found in the EEP.

\section{Acrylic Resin Specimen}

Wax patterns $(3.0 \times 2.5 \times 0.5 \mathrm{~cm})$ were invested with Type III dental stone (Herodent Soli Rock; Vigodent, Rio de Janeiro, RJ, Brazil) in metal (Uraby; DLC, São Paulo, SP, Brazil) or plastic dental flasks (Onda Cryl; Clássico Artigos Odontológicos Ltda., São Paulo, SP, Brazil) in accordance with the manufacturer's recommendations for each resin.

Hot water bath (Clássico Artigos Odontológicos Ltda., polymer, batch \# B-07 mV; monomer, batch \# CT-14) or microwave (Onda Cryl, polymer batch \# 8911.01; monomer, batch \# CT-23) PMMA denture bases were mixed in accordance with the manufacturer's recommendations and packed into molds at dough stage. Microwavable resin specimens were polymerized in a microwave oven (Continental AW-42, with 2,450 $\mathrm{GHz}$ frequency and $900 \mathrm{~W}$ maximum potency; Bosch, Manaus, AM, Brazil), in accordance with the manufacturer's instructions ( 3 min at $360 \mathrm{~W} ; 4$ min at $0 \mathrm{~W}$ and $3 \mathrm{~min}$ at $810 \mathrm{~W}$ ). Specimens polymerized by hot water bath were processed in an automatic polymerization unit (Termotron P-100; Termotron, Piracicaba, $\mathrm{SP}$, Brazil) at $74^{\circ} \mathrm{C}$ for $9 \mathrm{~h}$. Once processed, all flasks were allowed to bench cool for at least $2 \mathrm{~h}$. All acrylic resin samples were ground with wet 320-, 400-, 600and 1200-grit silicon carbide papers (Carbimet; Buehler, Lake Bluff, IL, USA) in a polishing machine (Arotec APL-4; São Paulo, SP, Brazil). Subsequently, the polishing of the surfaces to be evaluated for SR, contact angle (CA) and SFE was complemented on a bench lathe (P134R; Nevoni, São Paulo, SP, Brazil) with a roller brush, pumice stone paste (Herjos lot 05794; Probem, São Paulo, SP, Brazil) and water for $15 \mathrm{~s}$, followed by a wet polishing wheel and a chalk (Probem) and water slurry for $15 \mathrm{~s}$. Polishing of the other surface used to evaluate surface hardness (HD) was completed in a polishing machine with diamond paste (batch\# 6019, 
Impetch, Boksbrung, South Africa) and a cotton disk (batch\# PCIMP203, Impetch). To distinguish the surfaces, the surface to be used for HD evaluation received a superficial mark made with a bur in the middle of the top edge. Next, the specimens were rinsed with deionized water in ultrasound bath (Thornton, model T7, Inpec Eletrônica Ltda., São Paulo, SP, Brazil) for 2 min. All specimens were kept in water at $37^{\circ} \mathrm{C}$ for 1 week to release residual monomer (4). The surfaces of all specimens were evaluated for SR, CA and HD before and after the treatments.

\section{Surface Treatment}

Forty specimens of each PMMA resin were randomly assigned to 5 groups in accordance with the AAs used (Table 2). Each specimen was immersed in a plastic tube containing $25 \mathrm{~g}$ of PRO (G2 and G7) or orabase gel without EEP (G1 and G6), or $25 \mathrm{~mL}$ of NYS (G4 and G9), FLU (G5 and G10) or deionized water (G3 and G8). The solutions were changed daily. The tube supporting racks were covered with aluminum foil for protection against light and were stored at $35 \pm 2^{\circ} \mathrm{C}$ in a cabinet (model 002CB, Fanem LTDA, São Paulo, SP, Brazil) for 14 days.

In order to simulate denture use, specimens were brushed 3 times a day (morning, midday and evening) with a toothbrush and toothpaste (Sorriso; Palmolive, São Paulo, SP, Brazil) for $5 \mathrm{~s}$ with hand pressure, but avoiding toothbrush bristle deformation. Specimens were flushed with distilled water and dried with a disposable towel before being put back into the plastic tube.

\section{Surface Roughness Measurements}

SR $\left(R_{a}\right)$ of the acrylic specimens was measured using a profilometer (Surfcorder SE 1700, Kozaka Industry, Kozaka, Tokyo, Japan) accurate to $0.01 \mu \mathrm{m}$ with total measurement length of $3.2 \mathrm{~mm}$ and $0.5 \mathrm{~mm} /$ $\mathrm{s}$. Three readings were made for each specimen and a mean value was calculated.

\section{Surface Free Energy}

SFE was found by measuring the contact angle of a sessile drop of $15 \mu \mathrm{L}$ of deionized water (surface

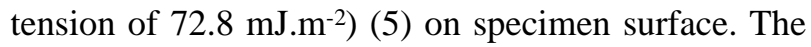
image of three drops for each specimen was captured with a digital camera with macro lens (Mavica CD350, Sony, Japan). An average for each specimen was calculated. Contact angle (CA) degree was measured using Auto Cad v.2005 software (Autodesk, CA, USA).

The contact angle cosine was used to calculate the SFE of the specimen. According to Gindl et al. (15), Neumann derived the following equation of the state of solid-liquid interfacial tension $\left(\gamma_{s} l\right)(16)$ :

$$
\gamma s l=\chi+\gamma-2 \sqrt{\chi \gamma s} \exp ^{-\beta(\chi-\gamma)^{2}}
$$

where $\beta$ is a constant with an average value of $0.0001057\left(\mathrm{~m}^{2} \mathrm{~mJ}^{-1}\right)^{2}, \gamma s$ is the surface tension of the solid and $\gamma l$ is the known surface tension of a liquid (15). When $\gamma s l$ is isolated in Young's equation [2] and substituted in equation [1] it results in equation [3].

$$
\gamma \cos (\Theta)=\not s-\not s l
$$

Equation [3] enables the SFE of a solid to be calculated from a single contact angle measurement $(\Theta)$ of a liquid with a known surface tension.

$$
\cos (\Theta)=-1 \frac{\chi-2 \sqrt{\chi \gamma s} \exp ^{-\beta(\chi-\gamma \delta)^{2}}}{\chi}[3]
$$

\section{Surface Hardness}

HD tests were performed using a microhardness tester (Shimadzu HMV-2000, Kyoto, Japan), using Knoop indenter with a $25 \mathrm{~g}$ load for $5 \mathrm{~s}$. Five indentations were made for each specimen at a distance of 150 $\mu \mathrm{m}$ between them and the average considered the value of microhardness for the specimen $\left(\mathrm{kgf} / \mathrm{mm}^{2}\right)$.

\section{Statistical Analysis}

SR and HD data were analyzed statistically and the assumptions of homogeneity of variances and normal distribution of errors were tested for the response variables evaluated. As data were not normally distributed, the SR data were transformed by square root and the HD data by $\log _{10}$. SFE was analyzed without transformation. Twoway ANOVA was used to test the null hypotheses of no 
difference among the PMMA resins and AAs and also the interaction between these factors, for each variable.Tukey's HSD test was used for post-hoc comparisons. Statistical analysis was done using SAS software (SAS Institute Inc., version 9.0 Cary, NC, USA) with the significance level set at $\alpha=0.05$.

\section{RESULTS}

The results of the 2-way ANOVA used to test the null hypothesis for each variable are shown on Table 1. The PMMA resin surfaces were affected by the exposure to the AAs. The surface of PMMA resins with regard to SR, SFE were not affected by the polymerization procedures by microwave or hot water bath when exposed to AAs ( $\mathrm{p}>0.05)$.

SR was influenced by the AAs (Table 1, $\mathrm{p}=0.018$ ). The highest SR values were obtained for PRO (Fig. 1). PRO also presented the highest values for CA, 63.51 $( \pm 2.8)$ before and $60.95( \pm 2.7)$ after surface treatment

Table 1. Two-way ANOVA comparison for SFE, HD and roughness.

\begin{tabular}{|c|c|c|c|c|c|c|}
\hline Variables & Source & DF & SS & MS & $\mathrm{F}$ & $p$ \\
\hline \multirow{3}{*}{ SFE } & Acrylic resin & 1 & 7.729 & 7.729 & 2.64 & 0.1065 \\
\hline & Antifungal Agent & 4 & 76.625 & 19.156 & 6.53 & $<0.0001$ \\
\hline & AcrilicResin x Antifungal Agent & 4 & 16.008 & 0.002 & 1.37 & 0.2488 \\
\hline \multirow{3}{*}{ HD } & Acrylic resin & 1 & 0.002 & 0.002 & 14.2 & 0.0002 \\
\hline & Antifungal Agent & 4 & 0.003 & 0.001 & 6.1 & 0.0001 \\
\hline & Acrilic Resin x Antifungal Agent & 4 & 0.001 & 0.000 & 1.79 & 0.133 \\
\hline \multirow{3}{*}{ SR } & Acrylic resin & 1 & 0.000 & 0.000 & 0.01 & 0.9394 \\
\hline & Antifungal Agent & 4 & 0.030 & 0.008 & 3.08 & 0.018 \\
\hline & Acrilic Resin x Antifungal Agent & 4 & 0.001 & 0.000 & 0.06 & 0.9927 \\
\hline
\end{tabular}

$\mathrm{SFE}=$ surface free energy; $\mathrm{HD}=$ Surface hardnes; $\mathrm{SR}=$ Surface roughness.

Table 2. Surface hardness $\left(\mathrm{kgf} / \mathrm{mm}^{2}\right)$ of the PMMA resins $(\mathrm{n}=8)$.

\begin{tabular}{lccc}
\hline & Antifungal agents & Day 0 & Day 14 \\
\hline & Orabase gel (control) (G1) & $18.4 \pm 0.6 \mathrm{a}$ & $18.3 \pm 0.3 \mathrm{a}$ \\
Heat-polymerized & Propolis orabase gel (G2) & $18.6 \pm 0.6 \mathrm{a}$ & $19.0 \pm 0.3 \mathrm{~b}$ \\
PMMA resin (A) & Deionized water (G3) & $18.2 \pm 0.4 \mathrm{a}$ & $18.1 \pm 0.3 \mathrm{a}$ \\
& Nystatin (G4) & $18.4 \pm 0.4 \mathrm{a}$ & $18.2 \pm 0.3 \mathrm{a}$ \\
& Fluconazole (G5) & $18.9 \pm 0.7 \mathrm{a}$ & $18.2 \pm 0.2 \mathrm{a}$ \\
& & & \\
Microwavable & Orabase gel (control) (G6) & $18.6 \pm 0.4 \mathrm{a}$ & $18.1 \pm 0.3 \mathrm{a}$ \\
PMMA resin (B) & Propolis orabase gel (G7) & $18.6 \pm 0.4 \mathrm{a}$ & $19.5 \pm 0.4 \mathrm{~b}$ \\
& Deionized water (G8) & $18.7 \pm 0.5 \mathrm{a}$ & $18.8 \pm 0.4 \mathrm{a}$ \\
& Nystatin (G9) & $18.8 \pm 0.6 \mathrm{a}$ & $18.7 \pm 0.5 \mathrm{a}$ \\
& Fluconazole (G10) & $18.9 \pm 0.6 \mathrm{a}$ & $18.6 \pm 0.3 \mathrm{a}$
\end{tabular}

Different lowercase letters indicate statistically significant differences among the AAs. Different uppercase letters indicate statistically significant differences between the PMMA resins (Tukey's HSD test, $\mathrm{p}<0.05$ ). 
(Fig. 2). SFE was affected by AA with statistically significant difference ( $p<0.0001$; Fig. 2).

HD was affected by the polymerization method with statistically significant differences $(p<0.001)$ between the PMMA resins in before and after treatments (Table 2). The HD of both PMMA resins varied according to exposure to AAs ( $\mathrm{p}<0.001)$. HD increased when the resins were immersed in PRO. In contrast, when they were exposed to the other AAs the HD decreased. Microwave PMMA resin differed significantly from that of water bath, showing significantly higher HD values when immersed in PRO $(\mathrm{p}<0.001)$.

\section{DISCUSSION}

The use of AAs such as FLU and NYS to treat CEC is well established. Its common recurrence $(9,11)$, however, results in the constant interaction of those agents, FLU and NYS, with the PMMA resin surface. Consequently, damage to the PMMA resin surface could eventually favor later colonization by Candida spp (1). In this study, PMMA resins immersed in AAs had their surface characteristics (SFE and SR) as hardness altered.

The time and exposure to AAs was responsible for the increased SR values of acrylic resins. Although the vehicles used to prepare the AAs had different chemical structures, both distilled water and carbopol gel were inert to PMMA. Continuous exposure increased SR, mainly when the resins were exposed to treatments with PRO. The increased roughness can be explained by the deposition of PRO on the PMMA resin surface. Although surface brushing was performed in a standardized way, it did not prevent propolis accumulation, which was visually detected. The deposition of orabase gel components on PMMA resins was also observed, since the SR of the groups exposed to orabase gel without Propolis (G1 and G6) also increased (Fig. 1). The presence of ethanol in gel preparation (both control and experimental groups) could be also considered a reason for roughness

Figure 2. Mean surface free energy of the PMMA resins according to the antifungal agents ( $\mathrm{n}=8$ each); error bars represent SD. Different letters indicate statistically significant differences among the antifungal agents $(\mathrm{p}<0.05)$. 
increase. However, the higher results in roughness for PRO when compared to its control are suggestive that principle active deposition is the main cause for this.

The contact angle formed on a PMMA resin surface was used to evaluate the wettability of this material and to calculate the SFE $(5,6)$. Immersion of PMMA resins in AA could alter their wettability due to the entrapment of water droplets in the pores of PMMA resins (7). This overruled the effects of AA on the PMMA resin surface, since no differences were detected between AAs. Although no significant differences between PMMA resins were found.

The SFE of PMMA resins was calculated by using deionized water. The results of the present study were similar to others (17-19). In this study, equation [3] of a liquid with known surface tension was used, as an alternative to the use of 3 or more different liquids to calculate the free energy of a solid surface $(5,6)$. Due to using only one liquid method, it was not possible to calculate the other SFE elements, such as acidic and basic components (15), which can be considered a limitation of this study.

In this study, PMMA resins showed significant differences of HD with higher values for microwavable resins $(p<0.05)$. Both acrylic resins treated with PRO showed significant differences in comparison with the other treatments ( $\mathrm{p}<0.05)$, with high HD values, whereas those immersed in water, NYS and FLU revealed lower values and no significant differences among them. These low values can be attributed to water sorption in the polymeric matrix of PMMA resins (4). The higher HD values found for groups of PRO after treatment, possibly, occurred as a result of propolis accumulation on PMMA resin surfaces.

This deposition can be regarded as a barrier to Candida spp. adhesion, considering the use of varnish on PMMA resin as suggested by Milillo et al. (20) Although PRO increased SR, this layer of propolis could even prolong its benefits to inflamed mucosa, considering its anti-inflammatory and skin healing properties.

Within the limits of this study, it was found that PMMA resins polymerized by hot water bath or microwave energy exposed to propolis showed surface alterations, mainly in roughness. Although this alteration might favor the recurrence of CEC, further studies are needed to verify the potential of using propolis as a treatment. The other AA solutions performed similarly to water, for the three variables tested.

\section{RESUMO}

A alta prevalência da candidose em usuários de prótese dental removível e a sua terapêutica com agentes antifúngicos (AA) está estabelecida. Contudo, o efeito dos AA sobre a superfície da resina de poli(metil-metacrilato) (PMMA) ainda não foi estudada. Assim, objetivou-se avaliar o efeito do fluconazol (FLU), nistatina (NYS) e gel orabase de própolis (GO) sobre a superfície de PMMA. Água deionizada e GO sem princípio ativo foram utilizadas como controles. Espécimes fabricados com PMMA polimerizada em banho de água ou com energia de microondas receberam acabamento e polimento e tiveram a rugosidade de superfície (RS), energia livre de superfície (ELS) e dureza Knoop (DK) mensuradas. Os tratamentos de superfície foram obtidos pela imersão dos espécimes nos AA durante 14 dias. Os resultados obtidos foram analisados por ANOVA para dois fatores e para a comparação, entre tratamentos e resinas, o teste de Tukey $(\alpha=0,05)$ foi utilizado. Os resultados mostraram que ambas as resinas aumentaram RS e ELS, mas não diferiram entre si ( $p>0,05)$. Os grupos tratados com própolis mostraram valores maiores de RS e diferente dos demais AAs ( $\mathrm{p}<0,05)$. Com relação a rugosidade e energia livre de superfície não foram encontradas diferenças entre as PMMAs e entre FLU e NYS. Concluiu-se que a própolis induziu modificações na superfície de PMMA aumentando a rugosidade, fator que poderá facilitar a adesão de microrganismos.

\section{REFERENCES}

1. Arendorf TM, Walker DM. Denture stomatitis: a review. J Oral Rehabil 1987;14:217-227.

2. Quirynen M, Bollen CM. The influence of surface roughness and surface-free energy on supra- and subgingival plaque formation in man. A review of the literature. J Clin Periodontol 1995;22:1-14.

3. Radford DR, Challacombe SJ, Walter JD. Denture plaque and adherence of Candida albicans to denture-base materials in vivo and in vitro. Crit Rev Oral Biol Med 1999;10:99-116.

4. Oliveira VM, Léon BL, Del Bel Cury AA, Consani S. Influence of number and position of flasks in the monomer release, Knoop hardness and porosity of a microwave-cured acrylic resin. J Oral Rehabil 2003;30:1104-1108.

5. Sipahi C, Anil N, Bayramli E. The effect of acquired salivary pellicle on the surface free energy and wettability of different denture base materials. J Dent 2001;29:197-204.

6. Combe EC, Owen BA, Hodges JS. A protocol for determining the surface free energy of dental materials. Dent Mater 2004;20:262-268.

7. Monsenego P, Baszkin A, Costa ML, Lejoyeux J. Complete denture retention. Part II: Wettability studies on various acrylic resin denture base materials. J Prosthet Dent 1989;62:308-312.

8. Kilani BH, Retief DH, Guldag MV, Castleberry DJ, Fischer TE. Wettability of selected denture base materials. J Prosthet Dent 1984;52:288-291.

9. Blomgren J, Berggren U, Jontell M. Fluconazole versus nystatin in the treatment of oral candidosis. Acta Odontol Scand 1998;56:202-205.

10. Force RW, Nahata MC. Salivary concentrations of ketoconazole and fluconazole: implications for drug efficacy in oropharyngeal and esophageal candidiasis. Ann 
Pharmacother 1995;29:10-15.

11. Bergendal T, Isacsson G. Effect of nystatin in the treatment of denture stomatitis. Scand J Dent Res 1980;88:446-454.

12. Koo H, Gomes BP, Rosalen PL, Ambrosano GM, Park YK, Cury JA. In vitro antimicrobial activity of propolis and Arnica montana against oral pathogens. Arch Oral Biol 2000;45:141-148.

13. Ellepola AN, Samaranayake LP. The in vitro post-antifungal effect of nystatin on Candida species of oral origin. J Oral Pathol Med 1999;28:112-116.

14. Koo MH, Park YK. Investigation of flavonoid aglycones in propolis collected by two different varieties of bees in the same region. Biosci Biotechnol Biochem 1997;61:367-396.

15. Gindl M, Sinn G, Gindl W, Reiterer A, Tschegg S. A comparison of different methods to calculate the surface free energy of wood using contact angle measurements. Colloid Surface Physicochem Eng Aspect 2001;181:279-287.

16. Neumann AW, Good RJ, Hoppe CJ, Sejpal M. An equation-ofstate approach to determine surface tensions of low-energy solids from contact angles. Journal of Colloid and Interface Science 1974;49:291-304.

17. Schakenraad JM, Busscher HJ, Wildevuur CR, Arends J. The influence of substratum surface free energy on growth and spreading of human fibroblasts in the presence and absence of serum proteins. J Biomed Mater Res 1986;20:773-784.

18. Busscher H, Pelt AV, Jong HD, Arends J. Effect of spreading pressure on surface free energy determinations by means of contact angle measurements. J Colloid Interface Sci 1983;95:23-27.

19. van der Valk P, van Pelt AW, Busscher HJ, de Jong HP, Wildevuur CR, Arends J. Interaction of fibroblasts and polymer surfaces: relationship between surface free energy and fibroblast spreading. J Biomed Mater Res 1983;17:807-817.

20. Milillo L, Lo Muzio L, Carlino P, Serpico R, Coccia E, Scully C. Candida-related denture stomatitis: a pilot study of the efficacy of an amorolfine antifungal varnish. Int $\mathrm{J}$ Prosthodont 2005;18:55-59.

Accepted July 21, 2008 